Geographic"”, to temat referatu dr Anety Rogalskiej-Marasińskiej (Uniwersytet Łódzki). Autorka przez nakreślenie obszarów pedagogicznych edukacji międzykulturowej na łamach prezentowanych w piśmie zdjęć, wskazała, jak ważnymi i wymownymi mogą być w swej treści obrazy. Dr Anna Haratyk (Uniwersytet Wrocławski) przedstawiła rolę współczesnych pism popularnonaukowych jako źródeł wiedzy historycznej i kulturowej, odwołując się do czasopisma regionalnego „Tatry”, ukazującego się na Podhalu od lat 90. XIX w.

Prof. dr hab. Alicja Kicowska (Uniwersytet Warmińsko-Mazurski w Olsztynie) zaprezentowała rolę czasopisma „Wiadomości Mazurskie” w rozwoju szkolnictwa rolniczego do roku 1956. Autorka wykazała indoktrynacyjny wpływ czasopisma sterowanego przez ówczesną władzę, gdzie m.in. dominowała tematyka szkół rolniczych przygotowujących do pracy w dużych gospodarstwach rolnych, jak PGR, pomijając zagadnienia indywidualnego rolnictwa (co łączyło się z ówczesną propagandą kolektywizacji rolnictwa). Kreację rzeczywistości społeczno-politycznej na łamach „Sztandaru Młodych” przed 1956 r. i jego propagandową rolę w kształtowaniu światopoglądu młodzieży szkolnej zaprezentowała dr Joanna Król (Uniwersytet Szczeciński). Dr Maria Radziszewska (Uniwersytet Warmińsko-Mazurskiego w Olsztynie) ukazała zamieszczane na łamach olsztyńskiej prasy lokalnej (w latach 1945-1989) problemy szkolnictwa Warmii i Mazur. Problematyka edukacji w czasopismach drugiego obiegu wydawanych w latach 19801989 była przedmiotem rozważań dr. Ryszarda Ślęczki (Uniwersytet Pedagogiczny w Krakowie).

Konferencja łódzka w sposób zasadniczy wykazała, jak ważnym źródłem dla badania przeszłości edukacyjnej są periodyki, których bogactwo i wszechstronność ukazuje jej wieloaspektowy obraz.

Justyna Gulczyńska

Katarzyna Kabacińska

\title{
Sprawozdanie z konferencji „Od grzechotki do klocków Lego - dawne i współczesne zabawki dziecięce" 7-8 grudnia 2009 Kielce
}

W dniach 7-8 grudnia 2009 r. w ramach obchodów 30-lecia powstania Muzeum Zabawek i Zabawy w Kielcach, w pięknym i nowym budynku Muzeum, odbyła się konferencja: „Od grzechotki do klocków Lego - dawne i współczesne zabawki dziecięce”. Organizatorami sesji byli: Wydział Studiów Edukacyjnych Uniwersytetu im. Adama Mickiewicza w Poznaniu, kieleckie Muzeum Zabawek i Zabawy oraz Uniwersytet Hu- 
manistyczno-Przyrodniczy im. Jana Kochanowskiego w Kielcach. Konferencji patronował Komitet naukowy, w którego skład weszli: prof. zw. dr hab. Dorota Żołądź-Strzelczyk oraz prof. dr hab. Wiesław Jamrożek (Uniwersytet im. Adama Mickiewicza w Poznaniu), prof. zw. dr hab. Ryszard Kantor (Uniwersytet Pedagogiczny im. KEN w Krakowie), dr Jolanta Podsiadło (dyrektor Muzeum Zabawek i Zabawy w Kielcach) oraz dr Małgorzata Pękowska i dr Ewa Kula (Uniwersytet Humanistyczno-Przyrodniczy im. Jana Kochanowskiego w Kielcach).

Przez wiele lat problematyka zabawek była, podobnie jak dziecko i czas dzieciństwa, tematem mało interesującym dla naukowców. W Polsce, dopiero w 2 połowie XX w. można dostrzec zainteresowanie zabawką. Do prekursorów badań naukowych nad zabawką należą m.in.: Jan Bujak, Wincenty Okoń, Bogusław Sułkowski, Teresa Lewińska, a w ostatnich latach Ryszard Kantor, Dorota Żołądź-Strzelczyk, Katarzyna Kabacińska. Zabawka towarzyszy dziecku przez cały okres dzieciństwa, może być wykonana z kunsztowną misterią artysty lub wyprodukowana w fabryce zabawek, ale może być zrobiona ze zwykłych materiałów przez samo dziecko.

Celem pierwszej konferencji poświęconej zabawce jako przedmiotowi zabawy było przede wszystkim pokazanie interdyscyplinarności badań, dlatego to spotkanie naukowe odbyło się w gronie osób z różnych ośrodków - środowisk zarówno akademickich, jak i pracowników muzeów z różnych regionów Polski, różnych specjalności - archeologów, etnologów, pedagogów, socjologów, historyków. W obradach uczestniczyło ponad 60 przedstawicieli wielu ośrodków naukowych i placówek muzealnych, m.in.: Wszechnicy Świętokrzyskiej, Uniwersytetu Gdańskiego, Uniwersytetu Mikołaja Kopernika w Toruniu, Uniwersytetu im. Adama Mickiewicza w Poznaniu, Uniwersytetu Pedagogicznego im. KEN w Krakowie, Uniwersytetu Rzeszowskiego, Uniwersytetu Kazimierza Wielkiego w Bydgoszczy, Uniwersytetu w Białymstoku, Wyższej Szkoły Biznesu w Dąbrowie, Akademii im. Jana Długosza w Częstochowie, Uniwersytetu Jagiellońskiego, Wyższej Szkoły Hotelarstwa i Turystyki w Częstochowie, Uniwersytetu Śląskiego, Uniwersytetu Opolskiego, Muzeum Etnograficznego im. Seweryna Udzieli w Krakowie, Muzeum Warmii i Mazur w Olsztynie, Muzeum Pierwszych Piastów na Lednicy, Muzeum Archeologicznego w Poznaniu, Muzeum Archeologiczno-Historycznego w Elblągu, Muzeum Okręgowego w Rzeszowie oraz Muzeum Wsi Opolskiej.

Obrady rozpoczęli i przywitali gości organizatorzy, w imieniu których głos zabrali: prof. dr hab. Dorota Żołądź-Strzelczyk, dr Jolanta Podsiadło, prezydent miasta Kielc Wojciech Lubawski oraz prof. dr hab. Marek Kątny, dziekan Wydziału Pedagogicznego i Artystycznego Uniwersytetu Humanistyczno-Przyrodniczego im. Jana Kochanowskiego w Kielcach. Obradom plenarnym przewodniczyła prof. dr hab. Dorota Żołądź-Strzelczyk (UAM). Pierwszy referat, dotyczący zabaw i zabawek dziecięcych w okresie niewoli narodowej, wygłosił prof. dr hab. Adam Winiarz (Wszechnica Świętokrzyska w Kielcach). Wywód swój oparł na bardzo obszernym materiale źródłowym, głównie pamiętnikarskim. Następnie głos zabrał prof. dr hab. Krzysztof Jakubiak (Uniwersytet Gdański), który omówił rolę zabawy i zabawek w polskich koncepcjach wychowania przedszkolnego z przełomu XIX i XX w. Profesor podkreślił ogromną rolę kobiet w rozwoju wychowania przedszkolnego. Szczególnie wyróżnił zasługi Marii Weryho-Rodzie- 
wiczówny, Stefanii Marciszewskiej oraz Natalii Cicimirskiej. Następnie prof. dr hab. Ryszard Kantor (Uniwersytet Pedagogiczny im. KEN w Krakowie) wygłosił referat „Zabawa i zabawka w antropologicznej koncepcji człowieka”. W swoim wystąpieniu zdefiniował pojęcie ,zabawy”, podkreślając różnice semantyczne w rozumieniu zabawy jako zachowania zwierząt i niemowląt. Profesor zaapelował także o zorganizowanie konferencji dotyczącej zabawek i zabaw dorosłych, co przyjęto z dużym entuzjazmem. Obrady plenarne zakończyło wystąpienie prof. dr hab. Haliny Mielickiej (Uniwersytet Humanistyczno-Przyrodniczy im. Jana Kochanowskiego w Kielcach), która w swoim wystąpieniu omówiła socjalizacyjne funkcje zabawy.

Pierwszego dnia konferencji naukowcy obradowali w trzech sekcjach: „Zabawki przeszłości - w badaniach archeologicznych”, „Zabawki przeszłości - w badaniach historycznych” oraz „Zabawki przeszłości - w zbiorach muzealnych (i kolekcjach prywatnych)". W sekcji archeologicznej, której przewodniczyła prof. dr hab. Dorota ŻołądźStrzelczyk, pierwsza głos zabrała mgr Izabela Gomółka (Uniwersytet Mikołaja Kopernika w Toruniu). Omówiła ona średniowieczne lalki drewniane, odnalezione podczas wykopalisk m.in. na terenie Kołobrzegu, Elbląga, Wolina i Gdańska. Następnie referat wygłosił mgr Jacek Wrzesiński (Muzeum Pierwszych Piastów na Lednicy), który przedstawił najstarsze zabawki dziecięce, w tym lalkę z epoki brązu z Panteileria oraz lalkę z grobu Crepereia Tryphaena (II w. n.e.). W swoim wystąpieniu omówił również pochówki dziecięce. Trzecia głos zabrała mgr Agnieszka Stempin (Muzeum Archeologiczne w Poznaniu) z referatem: „Szachy - średniowieczne zabawki edukacyjne”. Muzealniczka w bardzo atrakcyjny sposób przedstawiła historię i ewolucję tej gry oraz uwydatniła jej walory edukacyjne. Następnie referat wygłosił mgr Mirosław Marcinkowski (Muzeum Archeologiczno-Historyczne w Elblągu), który omówił zabawki, jakimi bawiły się dzieci Elblążan, począwszy od XIV w. Sesję zamknęło barwne wystąpienie mgr. Piotra Adamczyka (Muzeum Archeologiczno-Historyczne w Elblągu), który przywitał słuchaczy „zakuty w stal”. Muzealnik omówił ofertę edukacyjną swojej placówki, podkreślając ogromną rolę pedagogiczną zabawek. Pokazał, również zgromadzonym, kopie odnalezionych podczas wykopalisk w Elblągu zabawek, które są wykorzystywane jako pomoce naukowe podczas lekcji i imprez muzealnych.

W sekcji historycznej, której przewodnictwo objął prof. dr hab. Roman Tomaszewski, pierwsza wystąpiła dr Katarzyna Kabacińska (Uniwersytet im. Adama Mickiewicza), która omówiła spojrzenie na zabawkę w dawnych poglądach pedagogicznych, zwracając uwagę, że podjęcie tematyki zabawek jest tożsame z rozwojem zainteresowań naukowych nad dzieckiem i dzieciństwem. Następnie głos zabrał dr Jan Ryś (Uniwersytet Pedagogiczny im. KEN w Krakowie) z referatem „Dziecięce zabawki militarne”, w którym podkreślił ponadczasową specyfikę i rolę zabawek militarnych. Dr Ewa Barnaś-Baran (Uniwersytet Rzeszowski) ukazała wspierającą funkcję zabaw i zabawek w życiu dziecka galicyjskiego. Następnie wystąpiła mgr Kamila Juchcińska - Giłka (Uniwersytet K. Wielkiego w Bydgoszczy), wygłaszając referat: „Zabawy i zabawki dzieci chłopskich w II Rzeczpospolitej w świetle źródeł pamiętnikarskich”. Sesję popołudniową, pod przewodnictwem prof. dr hab. Krzysztofa Jakubiaka, rozpoczęło wystąpienie dr Moniki Nawrot-Borowskiej (Uniwersytet K. Wielkiego w Bydgoszczy), która 
omówiła zapatrywania teoretyczne na zabawy i zabawki dzieci w 2 połowie XIX w. oraz początku XX w. Mgr Agata Samsel (Uniwersytet w Białymstoku) skupiła swe refleksje wokół zabaw dzieci wiejskich w II Rzeczpospolitej. Z kolei prof. dr hab. Eleonora Sapia-Drewniak (Wyższa Szkoła Biznesu w Dąbrowie Górniczej) omówiła zabawy i zabawki dzieci z Górnego Śląska na początku XX w. Sesję historyczną zamknęło wystąpienie mgr Grażyny Pyli (Muzeum Etnograficzne im. Seweryna Udzieli w Krakowie), która wyjaśniła socjalizacyjną funkcję zabawek i zabaw w tradycyjnej kulturze chłopskiej.

W sekcji muzealniczej, której przewodniczył prof. dr hab. Adam Winiarz, obrady rozpoczęło wystąpienie mgr Anny Myśliwiec (Muzeum Zabawek i Zabawy w Kielcach), która omówiła zasoby zabawek w polskich muzeach, zwracając szczególną uwagę na kolekcje znajdujące w Muzeum Zabawek i Zabaw w Kielcach. Następnie głos zabrała mgr Teresa Lewińska (Warszawa), która scharakteryzowała kolekcje zabawek w zbiorach Państwowego Muzeum Etnograficznego w Warszawie. Sesję poniedziałkową zamknął referat mgr Kingi Jackowskiej (Muzeum Warmii i Mazur w Olsztynie), która omówiła zabawki oraz motywy ludyczne w zbiorach ikonograficznych Muzeum Warmii i Mazur w Olsztynie. Mgr Maria Ozierańska z Muzeum Zabawek „Bajka” w Kudowie Zdroju podzieliła się ze słuchaczami swoimi spostrzeżeniami na temat kolekcjonerstwa zabawek w swojej placówce, zapraszając wszystkich do odwiedzenia Muzeum.

Obrady sekcji muzealnej kontynuowano następnego dnia pod przewodnictwem prof. dr hab. Ryszarda Kantora. Pierwszy referat wygłosił mgr Michał Majowicz (Muzeum Okręgowe w Rzeszowie), który omówił zabawki PRL-owskie w kontekście wystawy „Prezent pod choinkę, czyli zabawka z duszą”. Jego wystąpienie, u wielu uczestników konferencji, przywołało radosne wspomnienia z dzieciństwa, kiedy to sami się bawili, skrycie marząc o zabawkach zagranicznych, dostępnych wówczas jedynie w sklepach Pewexu. Następnie głos zabrała mgr Małgorzata Oleszkiewicz (Muzeum Etnograficzne im. Seweryna Udzieli w Krakowie), która przedstawiła różnice między zabawką dziecięcą a rekwizytem obrzędowym, jednocześnie szeroko omawiając zabawki z kolekcji muzealnej, w tym m.in. „Żydki Emausowe” oraz wspaniałe krakowskie szopki. Sekcję zamknął referat mgr Damiana Drąga (Muzeum Okręgowe w Rzeszowie), w którym prelegent przedstawił techniczne aspekty wytwarzania i rozpowszechniania zabawek z ośrodka w Brzózie Stadnickiej, znajdujące się w zbiorach Muzeum Etnograficznego w Rzeszowie, zwracając szczególną uwagę na wytwórstwo drewnianych koni Jana Dudziaka.

Po zakończeniu obrad organizatorzy przygotowali dla uczestników wiele niespodzianek. Na początku „zabawkowego” wieczoru, zaproszono wszystkich do zwiedzania Muzeum Zabawek i Zabawy. Mgr Aneta Bąk, starszy kustosz Muzeum, przedstawiła historię placówki, scharakteryzowała zbiory i kolekcje, zabawiając słuchaczy ciekawymi anegdotkami. Po doznaniach estetycznych, w holu głównym Muzeum, mgr Bogdan Jasiński (Muzeum Wsi Opolskiej w Opolu) pokazał i omówił etapy powstawania gwizdków z gliny. Zaprosił wszystkich do lepienia tych zabawek. Wielu uczestników sesji naukowej, ubranych w białe, specjalnie przygotowane kombinezony, w atmosferze spontanicznej zabawy, lepiło gliniane gwizdki. W tym samym czasie pan dr Andrzej Nowak (Politechnika Opolska) opowiadał o swojej kolekcji porcelanowych gwizdków oraz pre- 
zentował muzyczne melodie „wygrywane” na gwizdkach. Wiele osób zapoznało się ze średniowiecznymi grami i zabawkami, które pokazał Piotr Adamczyk.

Drugiego dnia, oprócz sekcji muzealnej, obradowano w sekcjach: „Współczesne zabawki - konteksty edukacyjne", pod przewodnictwem prof. dr hab. Eleonory Sapii-Drewniak; w sekcji „Współczesne zabawki - zabawki terapeutyczne”, przewodniczyła prof. dr hab. Halina Mielicka oraz w sekcji „Współczesne zabawki - projektowanie i wytwórstwo" pod przewodnictwem prof. dr hab. Romana Tomaszewskiego.

W sekcji edukacyjnej pierwsze głos zabrały mgr Aleksandra Feliniak i mgr Agnieszka Herszel (Uniwersytet Łódzki), które szeroko omówiły fenomen lalki Barbie. Następnie referat pt.: „Zabawy i zabawki jako element edukacji regionalnej” wygłosiła mgr Aneta Bąk (Muzeum Zabawek i Zabawy), zwracając uwagę na wykorzystywanie zabawek z kolekcji Muzeum Zabawek i Zabawy podczas lekcji. Sekcję zamknęło wystąpienie dr. Tomasza Michalewskiego (Uniwersytet Opolski), który przedstawił wyniki przeprowadzonych przez siebie badań, dotyczących reminiscencji zabawek z dzieciństwa w świadomości studentów Uniwersytetu Opolskiego.

Piątą sekcję, skupioną wokół zabawek terapeutycznych, otworzył referat dr Marzeny Pękowskiej (Uniwersytet Humanistyczno-Przyrodniczy im. J. Kochanowskiego w Kielcach): „Zabawka jako pomoc dydaktyczna w szkole specjalnej w okresie międzywojennym", odwołujący się do bogatego materiału źródłowego. Następnie głos zabrała dr Elżbieta Minczakiewicz (Uniwersytet Pedagogiczny im KEN w Krakowie), która przedstawiła rolę zabawki w poznawczym i społeczno-emocjonalnym rozwoju dziecka specjalnej troski. Wystąpieniu dr E. Minczakiewicz, praktykowi z wieloletnim stażem, zajmującej się głównie dziećmi z Zespołem Downa, towarzyszyła pokaźna ekspozycja używanych przez nią na co dzień w pracy zabawek terapeutycznych. Na koniec wystąpiły mgr Katarzyna Kosno oraz mgr Anna Zielińska (Akademia im. Jana Długosza w Częstochowie), współtwórczynie, powstałej w 2007 r., Częstochowskiej Grupy Twórczej Zabawy. Panie zaprezentowały działalność i cele swojej organizacji, szeroko omawiając rolę zabawek edukacyjnych w procesie nauczania i rozwoju dzieci.

Ostatnią sekcję, dotyczącą projektowania i wytwórstwa zabawek, otworzył referat dr Moniki Banaś (Uniwersytet Jagielloński w Krakowie), która przedstawiła współczesne skandynawskie koncepcje projektowania zabawek. Następnie głos zabrały dr Barbara Pabian (Wyższa Szkoła Hotelarstwa i Turystyki w Częstochowie) z referatem „Częstochowski ośrodek zabawkarski wobec tradycji pielgrzymowania na Jasną Górę" oraz dr Magdalena Szalbot (Uniwersytet Śląski), która wygłosiła prelekcję zatytułową: „Etnolog w sklepie zabawkowym”. Mgr Bogdan Jasiński (Muzeum Wsi Opolskiej w Opolu) przedstawił referat dotyczący polskich ośrodków wytwarzania ceramicznych narzędzi muzycznych, popularnie zwanych po prostu gwizdkami.

Na zakończenie obrad wszyscy uczestniczy konferencji zostali zaproszeni do obejrzenia filmu pt. Zabawki ludowe. Podłazie woj. Kielce (1981; reżyserzy Krzysztof Chojnacki i Teresa Lewińska z Państwowego Muzeum Etnograficznego), który przedstawia proces wykonywania zabawek przez twórcę ludowego Jakuba Materka w Warszawie oraz do wysłuchania wystąpienia prywatnego kolekcjonera gwizdków, pana Andrzeja Nowaka. Po dyskusji i głosach refleksji, obrady zakończyła i dokonała podsumowania 
prof. dr hab. Dorota Żołądź-Strzelczyk, główna pomysłodawczyni i inicjatorka tego spotkania naukowego oraz dr Jolanta Podsiadło.

Konferencja „Od grzechotki do klocków Lego - dawne i współczesne zabawki dziecięce” nie tylko „udowodniła”, że tematyka świata zabawek, na pozór zepchnięta w niszę badań naukowych, jest znacząco obecna w wielu dziedzinach nauki. Interdyscyplinarne spotkanie wykazało, że mimo mówienia „specyficznym” językiem poszczególnych dyscyplin naukowych, wszyscy doceniają rolę zabawki w rozwoju i życiu dziecka oraz w historii samego dzieciństwa.

Owocem konferencji jest także podjęcie dalszych inicjatyw naukowych - spotkań poświęconych wieloaspektowym badaniom nad zabawką, która była, jest i będzie nadal bardzo ważnym towarzyszem dzieciństwa - czy tylko dzieciństwa?

Kinga Jackowska

Katarzyna Kabacińska

\section{Krakowskie środowisko historyków wychowania w drugiej połowie XX wieku (Kraków, 11-12 stycznia 2009)}

W stycznia 2009 roku odbyła się w Krakowie konferencja naukowa na temat: Krakowskie środowisko historyków wychowania w drugiej połowie XX wieku. Zorganizowała ją Katedra Historii Oświaty i Wychowania Uniwersytetu Pedagogicznego w Krakowie, którą wspierały Towarzystwo Historii Edukacji i Zakład Historii Oświaty i Kultury Uniwersytetu Jagiellońskiego. Konferencja spotkała się z dużym zainteresowaniem w środowisku historyków wychowania w całej Polsce.

W programie konferencji przewidziano spotkanie poświęcone jubileuszowi Profesora dr hab. Zygmunta Ruty oraz naukowe, które miało przedstawić dokonania krakowskiego środowiska historyków wychowania w drugiej połowie XX wieku i jego związkom z innymi ośrodkami naukowymi w Polsce. Uroczyste spotkanie pierwszego dnia, które odbyło się w Wieliczce, poświecone było jubileuszowi siedemdziesięciolecia urodzin i pięćdziesięciolecia pracy dydaktycznej oraz naukowej Profesora dr hab. Zygmunta Ruty. Uczestniczyli w nim: Dziekan Wydziału Humanistycznego Uniwersytetu Jagiellońskiego prof. dr hab. Andrzej Banach, Dziekan Wydziału Humanistycznego Uniwersytetu Pedagogicznego w Krakowie prof. dr hab. Kazimierz Karolczak, były Rektor Uniwersytetu Pelagicznego w Krakowie prof. dr hab. Feliks Kiryk oraz liczne grono przyjaciół i najbliższa rodzina Profesora. Ważnym punktem programu pierwszego dnia była laudacja na część Profesora Zygmunta Ruty wygłoszona przez prof. dr hab. Stanisława Gawlika i prof. dr hab. Krzysztofa Jakubiaka. Wygłaszający laudacje przedstawili drogę 